Науковий журнал "Комп'ютерно-інтегровані технологї̈: освіта, наука, виробництво" 41 Луиььк, 2019. Випуск № 36

DOI: $10.36910 / 6775-2524-0560-2019-36-8$

УДК 373.5:004

Корпяк Н.П.

Чернівецька спеціалізована школа I-III ступенів №22

\title{
НАВЧАЛЬНІ ПРОЕКТИ НА УРОКАХ ФІЗИКИ ІЗ ВИКОРИСТАННЯМ МУЛЬТИМЕДІЙНИХ ПРЕЗЕНТАЦЙ
}

Корпяк Н.П. Навчальні проекти на уроках фізики із використанням мультимедійних презентацій. У статті описано використання методу проектів на уроках фізики. При проведенні навчальних проектів використано експериментальний метод дослідження. В статті наведено чотири авторських навчальних проекти 3 фізики для учнів 7 класу, описано застосування сучасних вебсервісів для створення мультимедійних презентацій для демонстрації результатів, отриманих учнями при виконанні навчальних проектів. Описано захід «Фізика вихідного дня».

Ключові слова: метод проектів, фізика в сучасній школі, мультимедійні презентації, навчальні екскурсії.

Корпяк Н.П. Учебные проекты на уроках физики с использованием мультимедийных презентаций. В статье описано использование метода проектов на уроках физики. В статье приведены четыре авторских учебных проекта по физике для учащихся 7 класса, описано применение современных вебсервисов для создания мультимедийных презентаций для демонстрации результатов, полученных учащимися при выполнении учебных проектов. Описано мероприятие «Физика выходного дня». экскурсии.

Ключевые слова: метод проектов, физика в современной школе, мультимедийные презентации, учебные

Korpyak N.P. The Educational projects in physics classes with multimedia presentations usage. The article describes the usage of the method of projects in the physics classes. The article presents four educational projects for physics for the 7th grade students developed by authors, and describes the use of modern web services for creating multimedia presentations to demonstrate the results obtained by students in the execution of educational projects. The event "Physics on the day off" is described.

Keywords: method of projects, physics in modern school, multimedia presentations, study tours.

Постановка проблеми. Необхідною умовою формування ключових компетентностей учнів під час вивчення фізики в школі є їх включення у різні види активної навчально-пізнавальної діяльності 3 метою здобуття нових знань.

Виконання навчальних проектів і $є$ тим ефективним засобом, що сприяє успішному засвоєнню навчального матеріалу. Саме в процесі такої діяльності в учнів розвиваються пізнавальні навички, формуються вміння самостійно конструювати свої знання, орієнтуватися в інформаційному просторі, активно розвивати критичне мислення, розширювати сферу комунікації [1]. У проектній діяльності важливо створити ситуації для відчуття потреби у знаннях та продемонструвати здатність ефективного застосування цих знань. Проектна діяльність дозволяє учням здобувати знання у тісному зв'язку з реальною життєвою практикою, формує у них специфічні уміння розширювати свої пошукові зусилля, спрямовані на оптимальне вирішення поставленої проблеми. У роботі над проектами виявляється максимальна самостійність учнів у розвитку навичок дослідницької діяльності. Найпростіші дослідницькі проекти можна розпочинати виконувати 3 учнями вже 3 сьомого класу [2]. Такі проекти потребують добре обміркованої структури, продуманості методів збору експериментальних даних та їх опрацювання. Тому для їх виконання вчителю слід запропонувати учням план проведення навчального проекту, за яким можна виконати проект та спостерігати за перетворенням учнів, з таких, що знають мало на тих, що знають багато.

Аналіз останніх досліджень і публікацій. Порівняно 3 попередніми роками, зараз значно зросли вимоги до молодих людей, які закінчують школу. Сучасне суспільство зацікавлене не лише в тому, щоб випускники могли самостійно ухвалювати рішення і діяти, а і в тому, щоб вони могли самостійно набувати нові знання із використанням сучасних технологій та розуміти, де буде доречно їх застосувати, уміти генерувати нові ідеї, на високому рівні творчо обробляти інформацію та проводити різноманітні дослідження [3]. Такі вимоги спричиняють зміни різноманітних аспектів освіти. Проектна діяльність дозволяє формувати ключові компетентності учнів в середній школі, а сучасні інформаційні технології дозволяють робити це швидше і цікавіше для учнів. Інформаційні технології та технологія проектів доповнюють одна одну та дозволяють досягти бажаного результату сучасними методами.

Оскільки нова модель шкільної освіти передбачає орієнтацію на практичні навички та уміння застосувати отримані знання, важливим $є$ використання сучасних комп'ютерно-орієнтованих засобів навчання у проектній діяльності. Змінюються також вимоги до вчителя, тепер він має вміти 
проектувати ситуації, які б розвивали необхідні компетенції школярів, а також створювати умови для розвитку креативності учнів [4].

Метод проектів спрямований на створення позитивного настрою, на набуття знань на духовний розвиток учнів. При реалізації методу проектів змінюється роль вчителя і ставлення учнів до нього. Вчитель тепер не лише носій знань, а організатор пізнавальної діяльності. Він є незалежним консультантом, готовим розглянути колективну проблему, дати підказку чи вирішити труднощі, які виникли під час виконання проекту. Оскільки відбувається перехід від навчально-виховної до самостійної діяльності пошукового та творчого характеру, то покращується також психологічний клімат в класі [5]. Змінюється не лише роль вчителя, але і роль учнів. Вони вже не $є$ пасивними слухачами матеріалу, а мають можливість формувати критичне та аналітичне мислення, уміння обробляти інформацію. Під час виконання навчальних проектів, запропонованих вчителем, активізується пізнавальна діяльність. Таким чином, зростає мотивація до навчання.

Оскільки основна ідея проекту пов'язана $з$ реальним життям, зростає інтерес усіх учасників проекту до його виконання, а сучасні інформаційні технології стають не лише засобом пошуку i систематизації даних, а відкривають нові можливості для подання та презентування отриманих результатів. Принцип «навчання через дію» сприяє умінню добувати інформацію з різних джерел і використовувати інформаційні технології для ії представлення [6]. Проектна технологія $\epsilon$ потужним інструментом, що доповнює традиційні методи навчання.

Метод проектів має на меті розв'язати певну проблему, а це в свою чергу передбачає використання сукупності методів та засобів навчання та розвиває уміння інтеграції знань. В основі методу проектів $є$ ідея спрямованості на результат та знання, які можна отримати під час вирішення практично значимої проблеми. Важливо навчити дітей самостійно мислити, уміти прогнозувати можливі наслідки своїх дій та встановлювати причинно-наслідкові зв'язки, використовуючи знання 3 різноманітних галузей [7].

Метою статті $\epsilon$ висвітлення планів проведення навчальних проектів 3 фізики для учнів сьомих класів, зміст яких пов'язаний з дослідницькими проблемами, що показують прикладний характер фізичної науки та поглиблюють знання з предмету.

Виклад основного матеріалу. При проведенні навчальних проектів використовується експериментальний метод навчання, що включає в себе:

- формулювання мети експерименту;

- підготовку до проведення експерименту;

- розробку методу дослідження та проведення самого експерименту;

- спостереження, вимірювання;

- систематизацію отриманих даних;

- аналіз і узагальнення результатів експерименту;

- застосування отриманих результатів до розв'язування практичних завдань.

Розроблено чотири навчальних проекти з фізики для учнів 7 класу, плани яких наведено нижче.

\section{НАВЧАЛЬНИЙ ПРОЕКТ №1}

Тема. Вимірювання періоду обертання та обертової частоти ланиююгової каруселі.

Мета: виміряти період обертання та обертову частоту кабінок каруселі під час їх рівномірного руху по колу.

Вказівки до роботи

Підготовка до експерименту

Дайте відповіді на запитання:

1) Який рух називається рівномірним рухом по колу?

2) Що таке період обертання? За якою формулою обчислюється період обертання рівномірного руху тіла по колу.

3) Що таке обертова частота? За якою формулою обчислюється обертова частота?

\section{Експеримент}

Перед виконанням експерименту ознайомтеся з правилами безпеки експлуатації каруселі та сурово їх дотримуйтеся (рис. 1).

1) Виміряйте час $\boldsymbol{t}$, за який кабінка здійснює $\boldsymbol{N}$ оборотів.

2) Складіть та заповніть таблицю для визначення періоду обертання та обертової частоти кабінок каруселі.

Опрацювання результатів експерименту

1) Визначте період обертання. 
Науковий журнал "Комп'ютерно-інтегровані технологї̈: освіта, наука, виробництво" 43 Луиььк, 2019. Випуск № 36

2) Визначте обертову частоту.

Розрахунок подайте у вигляді задачі.

3) Спробуйте пояснити, чому під час обертання кабінки відхиляються від вертикалі.

Аналіз експерименту та його результатів

Проаналізуйте експеримент, зробіть висновок, у якому зазначте:

1) який рух ви вивчали;

2) значення яких фізичних величин ви визначили;

3) які результати отримали;

4) які чинники вплинули на точність результатів.

Додаткове завдання (Практикум з роз 'язування задач)

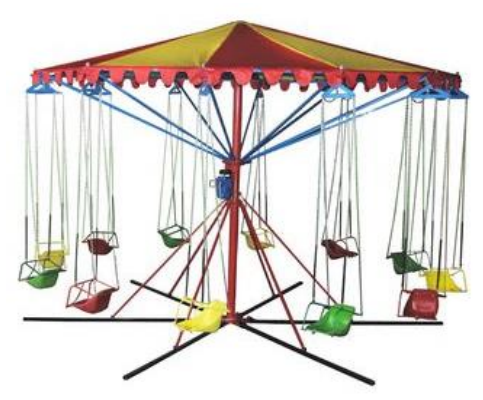

Рис.1. Ланцюгова карусель

Лінійна швидкість точок кола каруселі дорівнює $3 \mathbf{m} / \mathbf{c}$, а точок, що розташовані на відстані 2 $\boldsymbol{M}$ ближче до центра $-\mathbf{2} \boldsymbol{M} / \boldsymbol{c}$. Визначіть радіус каруселі, ії кутову швидкість, обертову частоту, період обертання каруселі та кількість обертів, здійснених нею за $2 \boldsymbol{x \boldsymbol { g }}$.

Тема. Дослідження коливань гойдалки.

\section{НАВЧАЛЬНИЙ ПРОЕКТ №2}

Мета: визначити амплітуду і період коливального руху гойдалки; переконатися, що період коливання гойдалки не залежить від амплітуди коливань та маси людини, що сидить на гойдалці.

Вказівки до роботи

Підготовка до експерименту

Дайте відповіді на запитання:

1) Що називають амплітудою коливань?

2) Що таке період коливань? За якою формулою обчислюється період коливань?

3) Що таке частота коливань? За якою формулою обчислюється частота коливань?

Експеримент

4) Чим відрізняються затухаючі і незатухаючі коливання?

Перед виконанням експерименту ознайомтеся 3 правилами безпеки експлуатації гойдалки та сурово їх дотримуйтеся (рис. 2).

1) Виміряйте час $\boldsymbol{t}$, за який гойдалка здійснює $\boldsymbol{N}$ коливань.

2) Складіть та заповніть таблицю для визначення періоду коливань та частоти коливань гойдалки.

Опрацювання результатів експерименту

1) Визначіть період коливань.

2) Визначіть частоту коливань.

3) Дослідіть, як залежить період коливань від амплітуди коливань гойдалки.

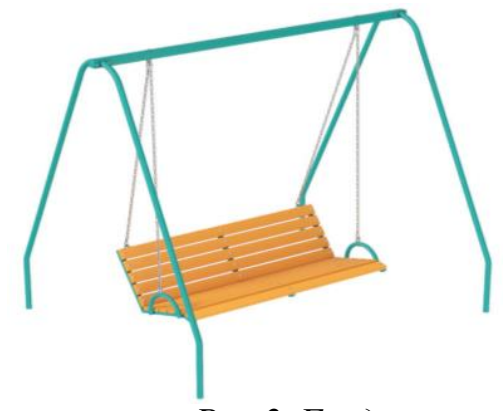

Рис.2. Гойдалка

4) Дослідіть, як залежить період коливань від маси людини, що сидить на гойдалці.

Розрахунок подайте у вигляді задачі.

Аналіз експерименту та його результатів

Проаналізуйте експеримент, зробіть висновок, у якому зазначте:

1) які величини ви навчилися вимірювати;

2) які чинники вплинули на точність одержаних результатів;

чи залежить період коливання гойдалки від амплітуди коливань та маси людини, що сидить на гойдалці.

Додаткове завдання

Доповніть речення:

Дівчинка сидить на гойдалці. Опором руху можна знехтувати.

1) Під час руху дівчинки вгору збільшується енергія і зменшується енергія;

2) У верхній точці траєкторії дівчинка на гойдалці має максимальну

3) Під час руху дівчинки вниз ............ енергія переходить у ............. енергію; 4) Під час руху у нижній точці траєкторії максимальною $\epsilon$............ енергія. енергію; 


\section{НАВЧАЛЬНИЙ ПРОЕКТ №3}

Тема. Зясування умови рівноваги гойдайки-важеля.

Мета: перевірити дослідним шляхом, яким є співвідношення сил і

іхніх плечей, щоб гойдалка-важіль перебувала у рівновазі.

Вказівки до роботи

Підготовка до експерименту

Дайте відповіді на запитання:

1) Що називають важелем і де застосовують важелі?

2) Що називають плечем сили?

Експеримент

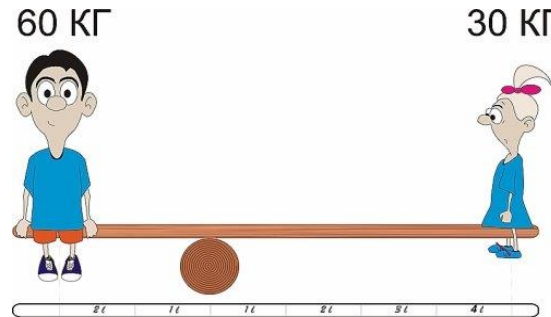

Рис.3. Гойдалка-важіль

Перед виконанням експерименту ознайомтеся з правилами безпеки експлуатації гойдалкиважеля та сурово їх дотримуйтеся (рис. 3).

1) Виміряйте відстані від осі обертання гойдалки-важеля до лінії дії сил.

2) Пригадайте масу свого тіла.

3) Складіть та заповніть таблицю для визначення фізичних величин, отриманих в результаті досліду.

Опрацювання результатів експерименту

1) Перевірте правильність виконання умови рівноваги важеля згідно з формулою.

2) Визначте 3 якою силою необхідно відштовхуватись ногами від землі одному з учнів, щоб гойдалка-важіль перебувала в рівновазі у випадку однакових довжин плечей сил та різних значень мас учнів.

Розрахунок подайте у вигляді задачі.

Аналіз експерименту та його результатів

На підставі проведених дослідів порівняйте відношення сил, що діють на гойдалку-важіль, і відношення ії плечей. Зробіть висновок, у якому:

1) сформулюйте умову рівноваги важеля;

2) проаналізуйте чинники, які вплинули на точність вимірювання.

Додаткове завдання (Практикум з розв'язування задач)

На кінцях гойдалки сидить хлопчик і дівчинка, масою 60 кг і 30 к2, довжина дошки 3 м. Де буде точка опори, якщо гойдалка в рівновазі?

\section{НАВЧАЛЬНИЙ ПРОЕКТ №4}

Тема. Дослідження руху тіла по колу.

Мета: ознайомитися з характеристиками руху тіла по колу.

Вказівки до роботи

Підготовка до експерименту

Дайте відповіді на запитання:

1) Що називається траєкторією руху?

2) Як можна визначити пройдений шлях при русі тіла по колу?

3) Що називається переміщенням?

4) Чи залежить траєкторія руху тіла, шлях і переміщення від вибору системи відліку?

\section{Експеримент}

Перед виконанням експерименту ознайомтеся 3 правилами безпеки експлуатації колеса огляду та сурово їх дотримуйтеся (рис. 4).

1) Поспостерігайте як здійснюється рух частин колеса огляду.

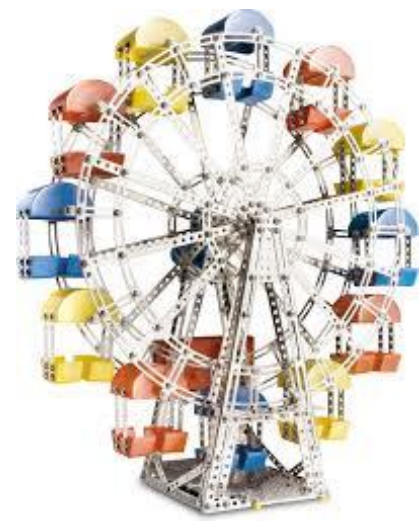

Рис.4. Колесо огляду

2) Дайте відповідь на запитання: які елементи колеса огляду рухаються поступально, а які здійснюють обертальний рух?

3) Накресліть схематичний рисунок, що зображає рух кабінок колеса огляду.

4) На рисунку вкажіть, яким $є$ переміщення тіла за $1 / 2,1 / 4$ періоду обертання та за повний період обертання.

Опрацювання результатів експерименту

1) Визначте пройдений шлях тіла за $1 / 2,1 / 4$ періоду обертання та за повний період обертання, прийнявши, що радіус колеса огляду дорівнює $\mathbf{5} \boldsymbol{м}$. 
Розрахунок подайте у вигляді задачі.

Аналіз експерименту та його результатів

Проаналізуйте експеримент, зробіть висновок, у якому зазначте:

1) який рух ви вивчали;

2) значення яких фізичних величин ви визначили;

3) які результати отримали.

Додаткове завдання (Практикум з розв'язування задач)

Уявіть, що ви вирішили протягом години кататись на колесі огляду. Яку відстань ви здолаєте за цей час, якщо діаметр колеса огляду дорівнює $\mathbf{5 0} \boldsymbol{M}$, а один оберт здійснюється за $20 \boldsymbol{x \boldsymbol { \theta }}$.

У Чернівецькій спеціалізованій школі I-III ступенів №22 було проведено захід «Фізика вихідного дня». Семикласники виконали навчальні проекти, відвідавши парк «Жовтневий» (рис 5.).

Учні самостійно обрали напрямки проектної діяльності. Аргументовано i емоційно ознайомились 3 планом проведення навчальних проектів. Колективно обговорили можливі варіанти їх виконання, узгодили дії учасників груп. Юні експериментатори на собі відчули дію фізичних законів та ще раз довели, що урок фізики може бути не тільки пізнавальним, а й веселим та захоплюючим.

Розроблені навчальні проекти можуть бути використані на етапі узагальнення та систематизації знань, а також повторення 3 тем «Рівномірний рух тіла по колу», «Коливальний рух. Амплітуда, період і частота коливань», «Умова рівноваги важеля» у курсі «Фізика. 7 клас».

Виконавцям кожного навчального проекту пропонується оформити звіт у вигляді презентації, в одному із сучасних вебсервісів:

- https://prezi.com/

- https://www.powtoon.com

- https://www.canva.com/

- https://haikudeck.com/

Сам термін «презентація» означає представлення чогось нового. Мультимедійна презентація - це представлення інформації 3 використанням мультимедійних технологій: відео, аудіо, 3D моделей, рисунків, фотографій, тексту, анімації та навігації. Мультимедійна презентація може бути інтерактивною, тобто, користувач, що переглядає презентацію, може певним чином впливати на матеріал, що відображається в той чи інший момент.

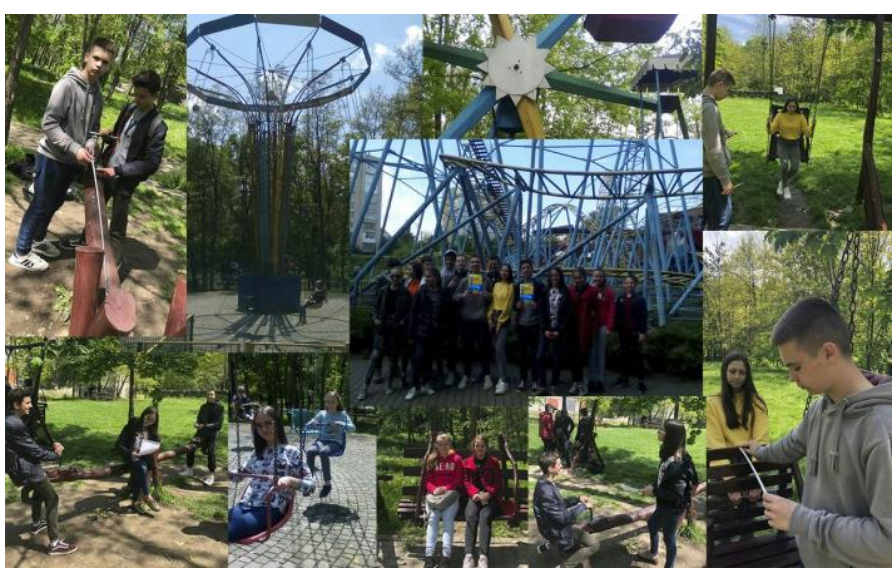

Рис.5. Захід «Фізика вихідного дня»

Особливу увагу варто надати сервісу https://prezi.com/. Prezi.com - це хмарний сервіс для створення презентацій, виконаних в новому стилі zoom-технології (технології наближення) та віртуальних історій, який базується на гнучкому використанні презентаційного полотна та дозволяє фокусувати деталі презентації. Рrezi-презентації створюються з допомогою інструменту редагування онлайн, що дозволяс імпортувати тексти, зображення, звуки, відео і т.д. Ці презентації зберігаються в мережі і можуть бути використані іншими користувачами в цілях мережевої взаємодії та обміну посиланнями. На відміну від звичних презентацій PowerPoint, у цьому середовищі можна створити цікаві нелінійні мультимедійні документи з нестандартними анімаційними переходами між слайдами. Важливою перевагою цього сервісу є можливість групової роботи над документом. Prezi.com - це угорський стартап, презентація в якому розміщується на одному великому віртуальному аркуші, а іiі демонстрація - це подорож по цьому аркушу з динамічним масштабуванням.

Велику роль в демонстрації презентації грає не лише показ слайдів, а і супровід звуком та анімацією. Використання презентацій на уроках фізики доводить, що пізнавальна мотивація учнів збільшується, полегшується оволодіння складним матеріалом. Презентація дозволяє наглядно впорядкувати матеріал та активізувати роботу класу. Працюючи над презентацією, кожен учень має можливість проявити свої креативні здібності в ії оформленні та в представленні матеріалу.

Висновки та перспективи подальшого дослідження. Реалізація методу проектів $\epsilon$ перспективною при вивченні фізики в школі. Робота над проектами викликає в учнів інтерес іє більш результативною, ніж традиційні уроки. Розроблені навчальні проекти можуть бути використані під час проведення нестандартних уроків фізики, для завдань літньої практики та навчальних екскурсій 3 
фізики. За наведеним зразком учні можуть створювати плани інших навчальних проектів для вивчення фізичних принципів роботи атракціонів.

Проектна діяльність передбачає залучення учнів до творчого пошуку, стимулює і посилює позитивну мотивацію до навчання, дозволяє вчитися на власному досвіді та досвіді інших, приносить моральне задоволення. Сучасний вчитель повинен бути не просто фахівцем у викладанні навчального предмету, але й педагогом-професіоналом, здатним розробляти авторські навчальні проекти, під час виконання яких учні з цікавістю здобували б нові знання.

1. Фізика: підруч. для 7 кл. загальноосв. навч. закл. за ред. В. Г. Бар'яхтара, С. О. Довгого. - Х.: Вид-во «Ранок», 2015. - $256 \mathrm{c}$.

2. Шарко В.Д. Сучасний урок фізики: технологічний аспект. - К.: СПД Богданова А.М., 2005. - 220 с.

3. Домбовська I. О. Актуальність використання проектних технологій у географічній освіті. - Таврійський вісник освіти. - 2017. - № 1 (57). - С. 65-69.

4. Тукало М. Д. Роль комп’ютерно орієнтованих засобів навчання в методі проектів при вивченні хімії у профільній школі. - Інформаційні технології і засоби навчання. - 2010 . - 12, № $4 . \quad-18$ c. http://dx.doi.org/10.33407/itlt.v12i4.86.

5. Бодько Л. Метод проектів як засіб реалізації особистісно орієнтованого навчання. - Початкова школа. - 2013. № 10. - С. 1-4.

6. Щеглова А. О. Місце проектного методу для формування і розвитку іншомовної комунікативної компетентності студентів в умовах змішаного навчання. - Інформаційні технології і засоби навчання. $-2016 .-53$, № 3. - С. $142-$ 149. http://dx.doi.org/10.33407/itlt.v53i3.1381.

7. Слободяник О. В. Реалізація методу проектів засобами соціальних мереж. - Інформаційні технології і засоби навчання. - 2016. - 56, № 6. - C. 30-39. http://dx.doi.org/10.33407/itlt.v56i6.1540.

1. Physics: textbook. for 7 cells. general education teach. closed in a row. V. G. Baryakhtar, S. O. Long. - X .: "Morning", 2015. $256 \mathrm{p}$.

2. Sharko VD Modern lesson in physics: technological aspect. - K .: SPD Bogdanova AM, 2005. - 220 p.

3. Dombovskaya IO The relevance of the use of design technologies in geographic education. - The Taurian Herald of Education. 2017. - No. 1 (57). - pp. 65-69.

4. Tukalo MD The role of computer-aided learning in project-based learning in chemistry at a specialized school. - Information technology and training. - 2010. - 12, № 4. - 18 p. http://dx.doi.org/10.33407/itlt.v12i4.86.

5. Bodko L. Method of projects as a means of realization of personally oriented learning. - Elementary School. - 2013. - № 10. - P. $1-4$.

6. Shcheglova AA The place of the project method for formation and development of students' foreign language communicative competence in blended learning. - Information technology and training. - 2016. - 53, No. 3. - P. $142-149$. http://dx.doi.org/10.33407/itlt.v53i3.1381.

7. Slobodian OV Implementation of the project method by means of social networks. - Information technology and training. - 2016. - 56, № 6. - P. 30-39. http://dx.doi.org/10.33407/itlt.v56i6.1540. 